\title{
The Adequacy of Radioiodine Control and Monitoring at Nuclear Fuels Reprocessing Plants
}

\author{
R. D. Scheele \\ L. L. Burger \\ J. K. Soldat
}

June 1984

Prepared for the U.S. Department of Energy under Contract DE-AC06-76RLO 1830

Pacific Northwest Laboratory Operated for the U.S. Department of Energy by Battelle Memorial Institute 


\title{
DISCLAIMER
}

This report was prepared as an account of work sponsored by an agency of the United States Government. Neither the United States Government nor any agency thereof, nor any of their employees, makes any warranty, express or implied, or assumes any legal liability or responsibility for the accuracy, completeness, or usefulness of any information, apparatus, product, or process disclosed, or represents that its use would not infringe privately owned rights. Reference herein to any specific commercial product, process, or service by trade name, trademark, manufacturer, or otherwise, does not necessarily constitute or imply its endorsement, recommendation, or favoring by the United States Government or any agency thereof. The views and opinions of authors expressed herein do not necessarily state or reflect those of the United States Government or any agency thereof.

\author{
PACIFIC NORTHWEST LABORATORY \\ operated by \\ BATTELLE \\ for the \\ UNITED STATES DEPARTMENT OF ENERGY \\ under Contract DE-AC06-76RLO 1830
}

\begin{tabular}{|c|c|}
\hline \multicolumn{2}{|c|}{$\begin{array}{l}\text { Printed in the United States of America } \\
\text { Available from } \\
\text { National Technical Information Service } \\
\text { United States Department of Commerce } \\
5285 \text { Port Royal Road } \\
\text { Springfield, Virginia } 22161\end{array}$} \\
\hline \multicolumn{2}{|c|}{$\begin{array}{l}\text { NTIS Price Codes } \\
\text { Microfiche A01 }\end{array}$} \\
\hline \multicolumn{2}{|c|}{ Printed Copy } \\
\hline Pages & $\begin{array}{l}\text { Price } \\
\text { Codes }\end{array}$ \\
\hline $001-025$ & $\mathrm{~A} 02$ \\
\hline $026-050$ & $\mathrm{~A} 03$ \\
\hline $051-075$ & $\mathrm{~A} 04$ \\
\hline $076-100$ & A05 \\
\hline $101-125$ & A06 \\
\hline $126-150$ & A07 \\
\hline $151-175$ & A08 \\
\hline $176-200$ & A09 \\
\hline $201-225$ & $A 010$ \\
\hline $226 \cdot 250$ & A011 \\
\hline $251-275$ & A 012 \\
\hline $276-300$ & $\mathrm{~A} 013$ \\
\hline
\end{tabular}


$\mathrm{PNL}-5108$

UC-86

THE ADEOUACY OF RADIOIODINE

CONTROL AND MONITORING AT

NUCLEAR FUELS REPROCESSING PLANTS

R. D. Scheele

L. L. Burger

J. K. Soldat

June 1984

Prepared for the U.S. Department of Energy under Contract DE-AC06-76RLO 1830

Pacific Northwest Laboratory

Richland, Washington 99352 
.

.

.

. 


\section{ACKNOWLEDGEMENTS}

The authors would like to thank all those who helped make this study possible. This work was sponsored by the U.S. Department of Energy, Office of Spent Fuel Management and Reprocessing Systems, under the direction of H. E. Stelling. The project manager at PNL was P. J. Meliinger. In particular, we would like to thank Loretta Maki and Carolyn Schauls for preparing and correcting the manuscript. 

CONTENTS

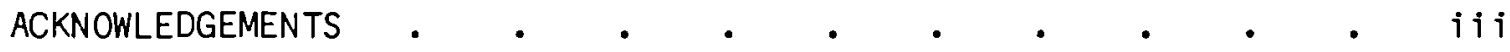





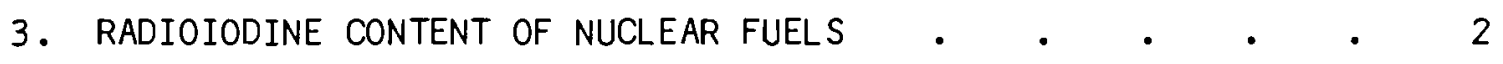

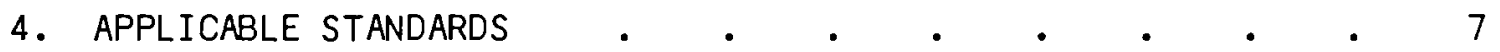

5. IODINE BEHAVIOR IN AN FRP $\quad$. $\quad . \quad$. $\quad . \quad$. $\quad . \quad 10$



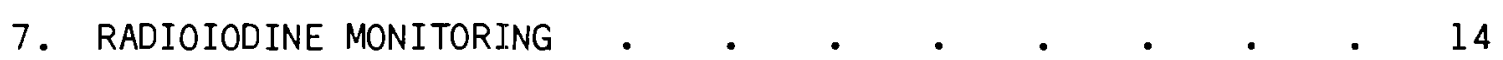

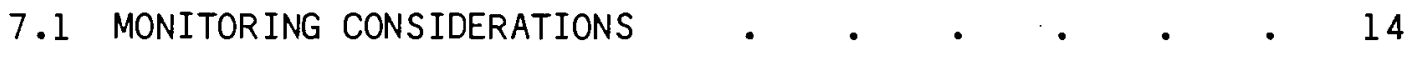

7.2 MONITORING STRATEGIES $\quad . \quad \cdot \quad \cdot \quad \cdot \quad \cdot \quad \cdot \quad \cdot \quad 15$

7.3 CURRENT MONITORING TECHNIOUES • • • • • • • 15

7.4 METHODS FOR RADIOIODINE MEASUREMENT $\quad$ • $\quad$ • $\quad$ • $\quad$ • 18

7.5 MONITORING FOR ADVANCED FUELS . • • • • • • 27

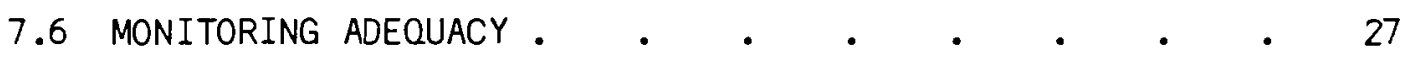



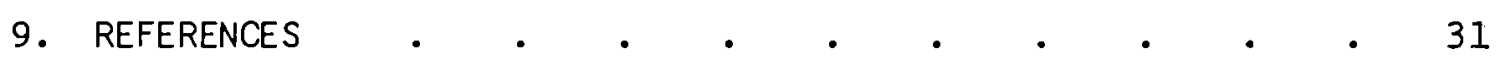




\section{EIGURES}

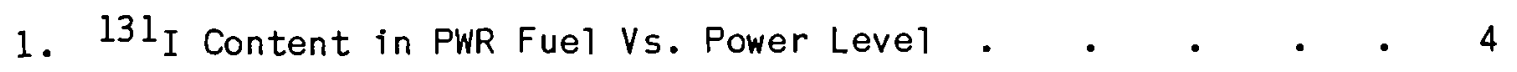

2. Radioiodine in Irradiated PWR Fuel Vs. Time After Shutdown a 6

3. ${ }^{129}$ I Content of Irradiated Fuel, 100 Days Post-Reactor . . 9

\section{TABLES}

1. Activity of ${ }^{129} \mathrm{I}$ and ${ }^{131^{1}}$ I in LWR Fuel at

Various Times After Reactor Shutdown $•$ • $\quad$ • $\quad$ • 5

2. Production of ${ }^{129} \mathrm{I}$ in LWR and LMFBR Fuel . . . . . . 8

3. Maximum Permissible Concentrations of Soluble



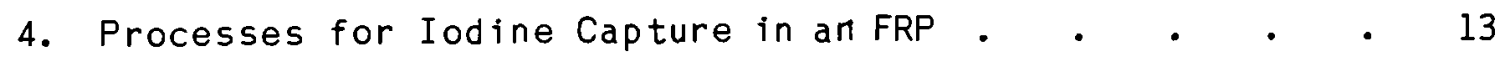

5. Sensitivity of Analytical Techniques for ${ }^{129} \mathrm{I}$. . . . . 19

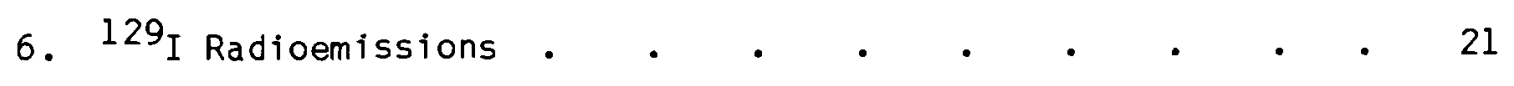

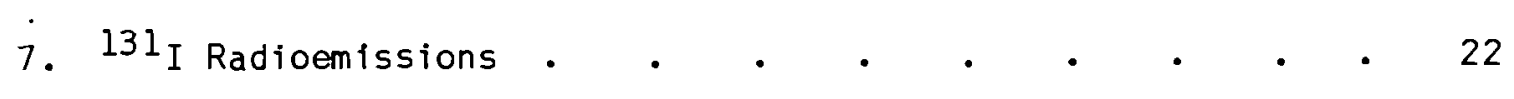


THE ADEOUACY OF RADIOIODINE CONTROL AND MONITORING

AT NUCLEAR FUELS REPROCESSING PLANTS

$$
\begin{aligned}
& \text { R. D. Scheele } \\
& \text { L. L. Burger } \\
& \text { J. K. Soldat }
\end{aligned}
$$

\section{SUMMARY}

The present backlog of irradiated reactor fuel leads to projections that no fuel out of the reactor less than 10 years need be reprocessed prior to the year 2000 . The only radioiodine present in such aged fuel is ${ }^{129} \mathrm{I}$ (ha) f-1 ife $1.6 \times 10^{7} \mathrm{yr}$ ). The ${ }^{131}$ I initial $1 \mathrm{y}$ present in the fuel decays to insignificance in the first few hundred days post-reactor.

The ${ }^{129}$ I content of irradiated fuel is about $1 \mathrm{Ci}$ per gigawatt-year of electricity generated (Ci/GW(e)-yr). The U.S. EPA has specified, in 40 CFR 190, a release 1 imit for ${ }^{129} \mathrm{I}$ of $5 \mathrm{mCi} / \mathrm{GW}(\mathrm{e})-\mathrm{yr}$. Thus a retention factor $(R F)^{(a)}$ of 200 for ${ }^{129}$ I at the fuel reprocessing plant (FRP) is required. Experience indicates that RF values obtained under actual. FRP operating conditions can average as 1 ittle as $10 \%$ of experimental ly determined RF values. Therefore processes theoretically capable of achieving RF values of up to $10^{4}$ have been investigated.

The U.S. EPA has also specified in 40 CFR 90 a thyroid dose 1 imit of $75 \mathrm{mrem} / \mathrm{r}$ for a member of the general public. This dose 1 imit could be readily met at a typical FRP site with an RF value of about 10 or 1 ess. Therefore, the 1 imit of $5 \mathrm{mCi} / \mathrm{GW}(e)-y r$ is more restrictive than the thyroid dose 1 imit for ${ }^{129} \mathrm{I}$.

The absence of ${ }^{131}$ I in effluents from processing of aged fuels makes analysis of ${ }^{129}$ I somewhat easier. However, in-1ine, real-time monitoring for ${ }^{129}$ I in FRP gas streams is currently not feasible. Moisture, chemicals, and other radioactive fission products interfere with in-plant

(a) Retention factor (RF) is the amount input divided by the amount output. 
measurements. Samples col lected over several days must be taken to a 1 aboratory for ${ }^{129}$ I analysis. Measurement techniques currently in use or under investigation include neutron activation analysis, scintillation counting, mass spectroscopy, and gas chromatography coupled with electron capture detection.

\section{INTRODUCTION}

The objective of this report is to review the current state-of-the-art and potential development of methods for control and monitoring of radioiodine in gaseous effluents at nuclear fuels reprocessing plants (FRP) with emphasis on ${ }^{129}$ I. Several technologies exist which are effective for radioiodine control; however, none of the techniques for iodine measurement are ful 1y adequate for simultaneous real-time monitoring of al1 the potential radioiodine isotopes present in an FRP. The adequacy of these methods is dependent upon existing and proposed government regulations concerning radionuclide concentrations and thyroid radiation doses.

In this report we emphasize ${ }^{129} \mathrm{I}$, since no reprocessing plant is currently, or is anticipating, processing fuels that have been out of the reactor less than the time required (250 days) for the ${ }^{131}$ I present in the fuel to decay to insignificance. In fact, recent projections are that no irradiated fuel less than 10 years old would need to be dissolved prior to

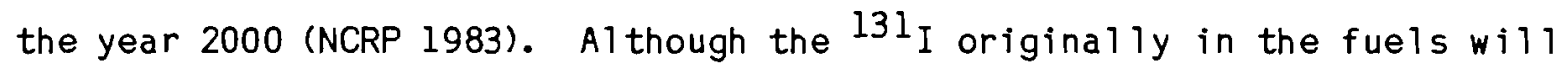
have decayed to negligible levels and ${ }^{129}$ I will be the on 1 y radioisotope of iodine present, some discussion of ${ }^{131} I$ control and monitoring is still necessary. This discussion is included here to provide a more complete, generic description of current practices and to provide a base for extrapolation to advanced and/or aged fuels.

\section{RADIOIODINE CONTENT OF NUCLEAR FUELS}

Production of ${ }^{129} \mathrm{I}$ and ${ }^{131} \mathrm{I}$ in nuclear power reactors is dependent upon the fissionable materials present $\left({ }^{235} \mathrm{U}\right.$ and $\left.{ }^{239} \mathrm{Pu}\right)$, the thermal power level of the reactor, and the total exposure of the fuel. For ${ }^{129} \mathrm{I}$ the 
production rate is proportional to the total exposure of the fuel, since it does not decay during production (half-life of $16 \mathrm{million}$ years). On the other hand, the relatively short- 1 ived ${ }^{13 l}$ I (half-life of 8 days) will decay during production and the equilibrium amount present in reactor fuels at the time of shutdown will be proportional to the power level at which the reactor operated. After reactor shutdown, the ${ }^{13 l}$ I content of the irradiated fuel will decrease quickly by radioactive decay, while the ${ }^{129} \mathrm{I}$ content will not. In fact, for the first few months there will be a small increase in content as the precursors decay into ${ }^{129} \mathrm{I}$. From then on, the ${ }^{129}$ I content remains essentially constant independent of the age of the fuel at the time of processing.

The thermal fission yields for both ${ }^{129} \mathrm{I}$ and ${ }^{13 l^{1}}$ I are significantly higher in ${ }^{239} \mathrm{Pu}$ than in ${ }^{235} \mathrm{U}$. Therefore, the quantities of these two radioiodines produced are also dependent upon the amount of ${ }^{239} \mathrm{Pu}$ that fissions during fuel irradiation. In a light-water power reactor (LWR) about $40 \%$ of the power is generated by fissioning of the ${ }^{239} \mathrm{Pu}$ produced from absorption of neutrons in $238_{U}$ during fuel irradiation. Thus the effective fission yields of both ${ }^{129} \mathrm{I}$ and ${ }^{131} \mathrm{I}$ are somewhat higher in LWRs than would be predicted on the basis of $235_{\mathrm{U}}$ fission only. Calculations made using the ORIGEN code (Croff, 1980) indicate that the net production of ${ }^{129} \mathrm{I}$ is about $1 \mathrm{\mu Ci}$ per megawatt-day (thermal) [MW(th)d] of fuel exposure. This is equivalent to about $0.4 \mathrm{Ci}$ per gigawatt-year (therma 1) [GW(th)yr]. If the fuel has received a nominal exposure of $33 \mathrm{GW}(\mathrm{th}) \mathrm{d}$ per metric ton of heavy metal ( $G W(t h) d / t$ ), then it would contain about $0.03 \mathrm{Ci}$ $129 \mathrm{I} / \mathrm{t}$.

The equilibrium content of ${ }^{13}{ }^{1}$ I in a LWR would be approximately $28 \mathrm{MC} i$ per GW(th). Thus, for a power level of $1 \mathrm{GW}(e)$ and a thermal efficiency of $30 \%$, there would be a total of $90 \mathrm{MCi}$ of ${ }^{131} \mathrm{I}$ in the reactor, or about 0.9 MCi per $t$ of fuel. Figure 1 illustrates the relationship between the equilibrium ${ }^{13 l_{I}}$ content in a PWR and the operating (thermal) power level of the reactor. Table 1 compares the abundance of ${ }^{129} \mathrm{I}$ and ${ }^{131} \mathrm{I}$ at various times after fuel irradiation to $33 \mathrm{GW}(\mathrm{th}) \mathrm{d}$ in a $1 \mathrm{GW}(\mathrm{e})$ LWR. This relationship is illustrated in Figure 2. 




FIGURE 1. ${ }^{131_{I}}$ Content in PWR Fuel Vs. Power Level 
IABLE 1. Activity of ${ }^{129}$ I and ${ }^{13 l_{I}}$ in, LWR Fuel at Various
Times After Reactor Shutdown

\begin{tabular}{|c|c|c|c|}
\hline \multirow{2}{*}{$\begin{array}{c}\text { Time After } \\
\text { Shutdown, days }\end{array}$} & \multicolumn{2}{|c|}{ Activity, Ci/t } & \multirow{2}{*}{$\begin{array}{c}\text { Ratio } \\
131_{I / 129}{ }^{2}\end{array}$} \\
\hline & ${ }^{129} \mathrm{I}$ & ${ }^{131} \mathrm{I}$ & \\
\hline 0 & 0.03 & $9 \times 10^{5}$ & $3 \times 10^{7}$ \\
\hline 30 & 0.03 & $7 \times 10^{4}$ & $2 \times 10^{6}$ \\
\hline 60 & 0.03 & $5 \times 10^{3}$ & $2 \times 10^{6}$ \\
\hline 100 & 0.03 & 200 & $5 \times 10^{3}$ \\
\hline 150 & 0.03 & 2 & 70 \\
\hline 200 & 0.03 & 0.03 & 1 \\
\hline 250 & 0.03 & $4 \times 10^{-4}$ & 0.01 \\
\hline 365 & 0.03 & $2 \times 10^{-8}$ & $6 \times 10^{-7}$ \\
\hline 600 & 0.03 & $3 \times 10^{-17(b)}$ & $9 \times 10^{-16}$ \\
\hline$>600$ & 0.03 & 0 & 0 \\
\hline
\end{tabular}

(a) Fuel irradiated to $33 \mathrm{GW}(\mathrm{th}) \mathrm{d} / \mathrm{t}$ in a $1-\mathrm{GW}(\mathrm{e})$ PWR.

(b) This corresponds to 1 atom $131_{I / t}$. 


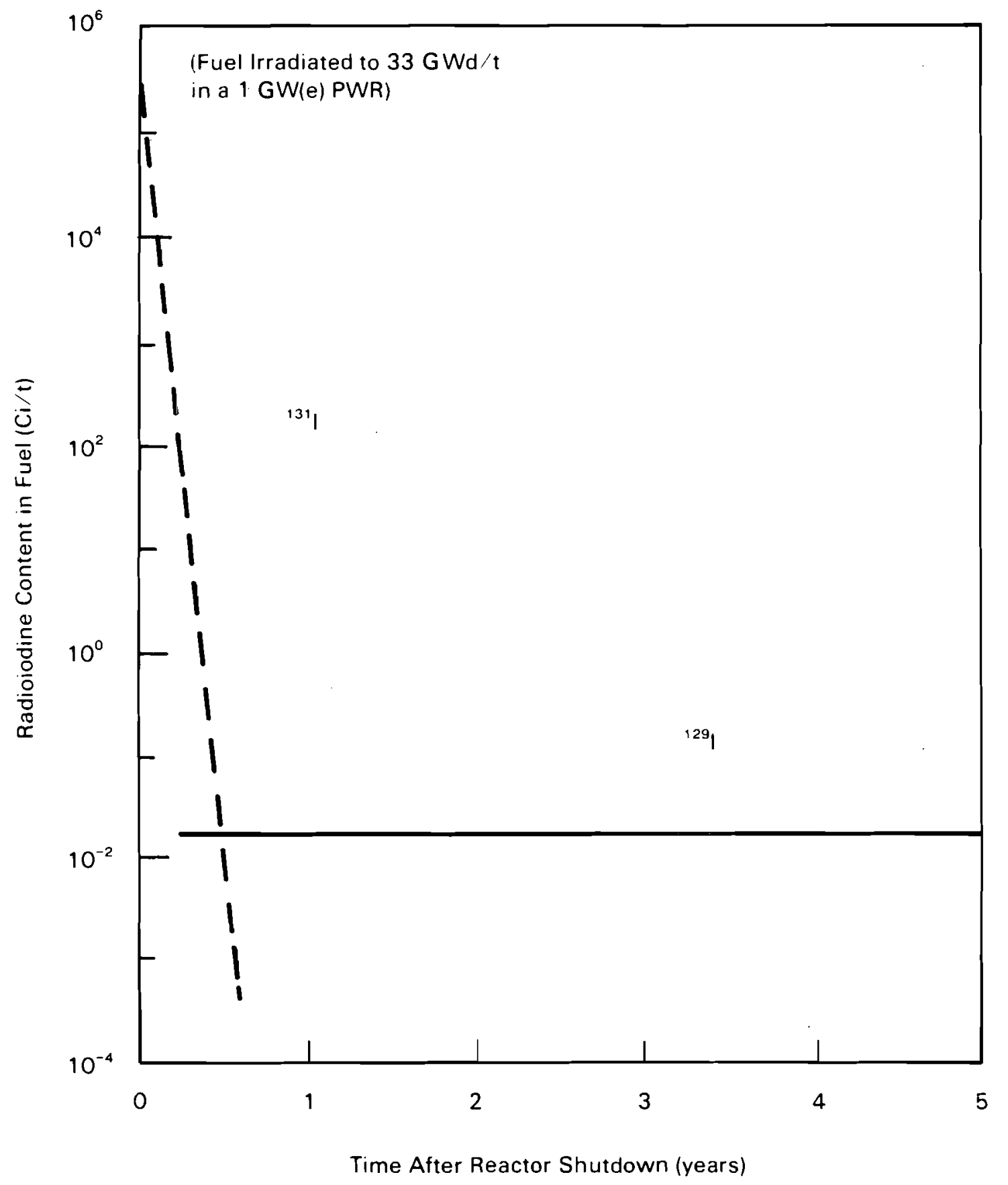

FIGURE 2. Radioiodine in Irradiated PWR Fuel Vs. Time After Reactor Shutdown 
The ORIGEN code was used to estimate the ${ }^{129}$ I production rate in conceptual breeder reactor fuel (LMFBR) at exposures of 75 and $100 \mathrm{GWd} / \mathrm{t}$. Because of the 1 arger number of ${ }^{239} \mathrm{Pu}$ fissions in the LMFBR fuel, the ${ }^{129} \mathrm{I}$ production rate per unit fuel exposure is about $30 \%$ higher than in LWR fue 1. Table 2 summarizes the production rate of ${ }^{129}$ I in PWR and LMFBR fuel calculated using the ORIGEN code and also includes data reported by Trevorrow et a1. (1983). These data are further illustrated in Figure 3.

Projections of the quantities of ${ }^{129} \mathrm{I}$ produced in irradiated fuels to be discharged from power reactors in the future are given in a recent report by the NCRP (1983). The authors of the report estimate that the cumulative amount of ${ }^{129} \mathrm{I}$ in irradiated fuels discharged from U.S. nuclear power reactors up through the year 2000 would be $2500 \mathrm{Ci}$. At that time ${ }^{129}$ I would be accumulating at the rate of $160 \mathrm{Ci} / y e a r$.

The worldwide nuclear power industry is projected to produce a total of $3700 \mathrm{Ci}$ of ${ }^{129} \mathrm{I}$ by the year 2000 (NCRP 1983). The report assumed a RF of 500 for collection of ${ }^{129}$ I from effluent gases at the FRP, so that a total of approximately $7 \mathrm{Ci}$ of ${ }^{129} \mathrm{I}$ would be released to the atmosphere when al 1 of the irradiated fuel generated by the year 2000, worldwide, would eventual 1 y be processed at an FRP.

The NCRP report only briefly discusses existing and potential ${ }^{129} \mathrm{I}$ control technology, monitoring methods, and analytical methods. The major emphasis in the report is on the sources of ${ }^{129}$ I and the potential radiation doses recelved by the public therefrom.

\section{APPLICABLE STANDARDS}

The U.S. Nuclear Regulatory Commission has publ ished concentration 1 imits for ${ }^{129} \mathrm{I}$ and ${ }^{131} \mathrm{I}$ in the environment (10 CFR 20 1983). The values for soluble iodine (which are more restrictive than those for insoluble iodine) are presented in Table 3 for a Control led Area and an Uncontrol led Area.

The U.S. DOE Order 5480.1 A, Chapter XI, Attachment XI-1, (U.S. DOE 1981) contains concentration guidelines for ${ }^{129} \mathrm{I}$ and ${ }^{131} \mathrm{I}$ in Uncontrol led 
IABLE 2. Production of ${ }^{129} I$ in LWR and LMFBR Fuel

\begin{tabular}{|c|c|c|c|c|}
\hline \multirow{2}{*}{$\begin{array}{l}\text { Fue1 Exposure } \\
\text { GWd/t }\end{array}$} & \multicolumn{2}{|c|}{ PWR Fuel } & \multicolumn{2}{|c|}{ LMFBR Fue 1} \\
\hline & $\mathrm{mCt} / \mathrm{t}$ & $\mu \mathrm{Ci} / \mathrm{MWd}$ & $\overline{\mathrm{mCi} / \mathrm{t}}$ & ${ }_{\mu} \mathrm{Ci} / \mathrm{MWO}$ \\
\hline 10 & $8.7^{(a)}$ & $0.87^{(a)}$ & -- & $1.2^{(\mathrm{c})}$ \\
\hline 20 & $18.4^{(a)}$ & $0.92^{(a)}$ & -- & $1.3^{(c)}$ \\
\hline 27.5 & $26^{(b)}$ & $0.95^{(b)}$ & -- & $1.3^{(c)}$ \\
\hline 30 & $28^{(a)}$ & $0.94^{(a)}$ & - & $1.3^{(c)}$ \\
\hline 33 & $32^{(b)}$ & $0.97^{(b)}$ & -- & $1.3^{(c)}$ \\
\hline 40 & $38^{(a)}$ & $0.96^{(a)}$ & -- & $1.3^{(c)}$ \\
\hline 50 & -- & $0.97^{(c)}$ & - & $1.3^{(c)}$ \\
\hline 60 & -- & $0.97^{(c)}$ & -- & $1.3^{(c)}$ \\
\hline 64.8 & -- & $0.97^{(c)}$ & $90^{(b)}$ & $1.4^{(b)}$ \\
\hline 75 & -- & $0.97^{(c)}$ & $96^{(a)}$ & $1.3^{(a)}$ \\
\hline 100 & - & $0.97^{(c)}$ & $127^{(a)}$ & $1.3^{(a)}$ \\
\hline
\end{tabular}

(a) Calculated by C. M. Heeb, PNL, using the ORIGEN code (Croff 1980).

(b) From Trevorrow, et a 1. (1983).

(c) Extrapolated from calculated values.

IABLE 3. Maximum Permissible Concentrations of Soluble Radiotodine in Air (10 CFR 20 1983)

\begin{tabular}{|c|c|c|c|c|}
\hline \multirow[b]{2}{*}{ Units } & \multicolumn{2}{|c|}{ Controlled Area } & \multicolumn{2}{|c|}{ Uncontrolled Area } \\
\hline & $129_{I}$ & $131_{I}$ & $129_{I}$ & $131_{I}$ \\
\hline$\mu \mathrm{Ci} / \mathrm{m} 1$ & $2 \times 10^{-9}$ & $9 \times 10^{-9}$ & $2 \times 10^{-11}$ & $1 \times 10^{-10}$ \\
\hline $\mathrm{pCi} / \mathrm{m}^{3}$ & $2 \times 10^{3}$ & $9 \times 10^{3}$ & 20 & 100 \\
\hline$\mu \mathrm{mol} I / L$ & $9 \times 10^{-5}$ & $6 \times 10^{-13}$ & $9 \times 10^{-7}$ & $6 \times 10^{-15}$ \\
\hline
\end{tabular}



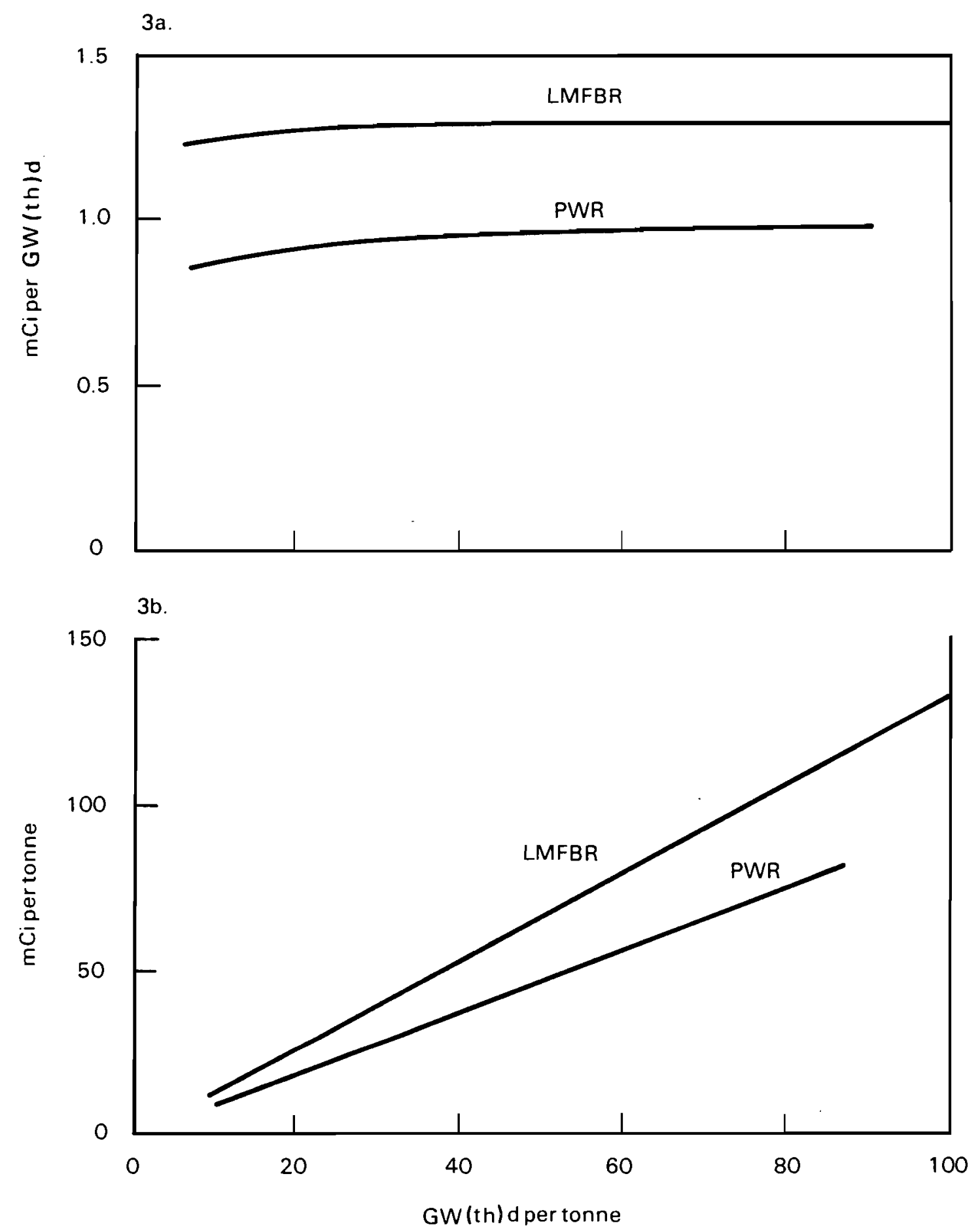

FIGURE 3. ${ }^{129}$ I Content of Irradiated Fuel 100 Days Post-Reactor 
Areas that are identical to those of the U.S. NRC, given in Table 3 . However, the values 1 isted in the DOE Order for both ${ }^{129} \mathrm{I}$ and ${ }^{131} \mathrm{I}$ in Controlled Areas are lower than those of the NRC. The DOE value for ${ }^{129}$ I in air of a Control led Area is $8 \times 10^{-10} \mu \mathrm{Ci} / \mathrm{mL}$ and for ${ }^{13} \mathrm{l}_{\mathrm{I}}$ the DOE value is $4 \times 10^{-9} \mu \mathrm{Ci} / \mathrm{mL}$. The DOE values reflect a maximum permissible annual dose of 15 rem, whereas the NRC values are still based upon the older occupational 1 imit of 30 rem for the thyroid.

The U.S. Environmental Protection Agency (EPA) has set 1 imits for the combined exposure of the public to radiation from al 1 phases of the LWR uranium fuel cycle. The 1 imits for the individual member of the public are $75 \mathrm{mrem} / \mathrm{yr}$ to the thyroid and $25 \mathrm{mrem} / \mathrm{yr}$ to any other organ or to the tota 7 body. The EPA thyroid dose 1 imit is $1 / 20$ of that specified in 10 CFR 20 (1983), and DOE order 5480.1A (1981).

To demonstrate compliance with this EPA requirement, radiolodine monitoring capabilities would have to be about an order of magnitude more sensitive than required by the 1983 U.S. NRC requirements.

In addition, the U.S. EPA has, in their 40 CFR 190, stated 1 imits for the rate of release of certain radionucl ides to the environment from the LWR fuel cycle. The $1 \mathrm{imit}$ for ${ }^{129} \mathrm{I}$ is $5 \mathrm{mCl} / \mathrm{GW}(\mathrm{e}) \mathrm{yr}$. The ${ }^{129} \mathrm{I}$ generation rate in PWR power reactor fuel is about $1 \mathrm{Ci} / \mathrm{GW}(e) y r$. To meet the EPA limit for ${ }^{129}$ I release rate, the iodine collection system at an FRP must therefore maintain a long-term average RF of 200 during actual operation. Such an RF, coupled with subsequent atmospheric dilution, would also control the environmental concentrations of ${ }^{129}$ I to values wel 1 below those corresponding to the $75 \mathrm{mrem}$ yr thyroid dose $1 \mathrm{imit}$. Past experience indicates that the RF actually achieved during operation is on 1 y $10 \%$ to $20 \%$ of the experimental RF, because of unforeseen chemical interferences and occasional process upsets.

\section{IODINE BEHAVIOR IN AN FRP}

The expected principal iodine path in an FRP is via the dissolver off gas (DOG). The actual iodine distribution will be determined by the 
process design. The iodine not volatilized becomes part of the high-level waste and may be recovered during high-level waste treatment.

There are many different chemical species of lodine present in the DOG. Elemental iodine $\left(\mathrm{I}_{2}\right)$ predominates, but smal1 quantities of organic iodides (primarily $\mathrm{CH}_{3} \mathrm{I}$ ) are also present. Particulate matter also carries an appreciable amount of lodine.

In addition to the many species of lodine, the DOG also contains oxides of nitrogen $\left(N O_{x}\right),{ }^{85} \mathrm{Kr}$, air, water, acids, some organic compounds, and particulates.

Treatment of the DOG to control release of these other gaseous components affects the concentration of iodine in the DOG. The DOG treatment strategy includes control of the amount of air introduced at the dissolver and the use of several types of condensers and aqueous scrubbers for retention of non-iodine DOG components; some of these steps may collect varying amounts of the iodine from the $D O G$.

The iodine concentration in the DOG may range from saturation (40 $\mu \mathrm{mol}$ $I / L$ at $\left.25^{\circ} \mathrm{C}\right)(\mathrm{a})$ down to as 1 ow as $10 \%$ or even $1 \%$ of this. Hower and Pence (1978) estimate that the average iodine concentration in the DOG would be $2 \mu \mathrm{mol} \mathrm{I} / \mathrm{L}$ ahead of the lodine collector, and approximate 1 y $10^{-2} \mathrm{Hmol} \mathrm{I} / \mathrm{L}$ downstream. They also estimate a stack concentration of $10^{-6} \mu \mathrm{mol} \mathrm{I} / \mathrm{L}$. Their analysis assumes LWR uranium fuel with a burnup of $33 \mathrm{GW}(\mathrm{th}) \mathrm{d} / \mathrm{t}$ which has been cooled 365 days. B. L. Taylor (1981) calculated that for a typical $7 \mathrm{t} / \mathrm{d}$ plant processing $40 \mathrm{GW}(\mathrm{th}) \mathrm{d} / \mathrm{t}$ fuel, the concentration in the DOG would be 0.08 to $0.8 \mu \mathrm{mol}{ }^{129} \mathrm{I} / \mathrm{L}\left(2-20 \mu \mathrm{Ci}{ }^{129} \mathrm{I} / \mathrm{m}^{3}\right)$. After the 1 ast iodine collector, the concentration would be $8 \times 10^{-5}$ to $8 \times 10^{-4} \mu \mathrm{mol}$ ${ }^{129} \mathrm{I} / \mathrm{L} \quad\left(2-20 \mathrm{nCi}{ }^{129} \mathrm{I} / \mathrm{m}^{3}\right)$.

A1 1 of these factors combine to complicate both the control and monitoring of iodine releases to the environment. However, it is expected

(a) $1 \mu \mathrm{mol}$ of ${ }^{129} \mathrm{I}=2.25 \times 10^{-8} \mathrm{Ci}, 1 \mu \mathrm{mol}$ of ${ }^{13 l} \mathrm{I}=16.2 \mathrm{Ci}$. 
that $99 \%$ of the lodine will be released from the fuel to the DOG (Brown, Christian, and Thomas 1983).

\section{PROCESSES FOR IODINE CONTROL}

The technologies available for control of iodine in an FRP (summarized in Table 4) are of two types, 1 iquid scrubbers and sol id sorbers. The foll lowing discussion is a summary of a recent document by Burger and Scheele (1983) on radioiodine control.

The silver-based sorbers, silver zeol ite (silver mordenite) and amorphous silica impregnated with silver nitrate $\left(A C-6120^{\circledR}\right)^{(a)}$ are the technologies currently recommended, based on efficiency and convenience of use. With these sorbers an RF $>10^{4}$ can be achieved. The silver sorbers have been demonstrated to be effective lodine traps, but the operating conditions have not been optimized to obtain the most efficient silver usage, thus minimizing cost and reducing the loss of a valuable resource. In addition, the chemistries of the capture processes are not wel 1 understood and require further study. Such additional studies would al low the design of and selection of the operating parameters for the iodine control system to accommodate occasional fluctuations or perturbations in the normal operation of the FRP.

The 1 iquid scrubbers which have been used or proposed for use in an FRP are caustic, Mercurex, and Iodox. Caustic scrubbers are useful for $\mathrm{I}_{2}$ but not organic iodides; RFs ranging from 10 to $10^{3}$ have been reported for

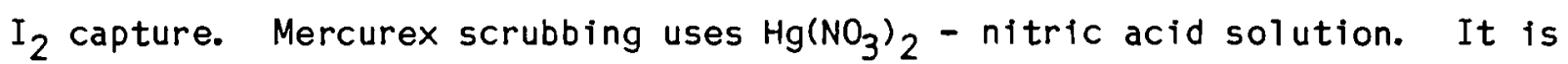
effective for both $\mathrm{I}_{2}$ and organic iodides if the acidity is $>8 \mathrm{M}$. A practical RF for Mercurex scrubbing is $10^{2}$. Iodox scrubber uses hyperazeotropic $\mathrm{HNO}_{3}$ to trap al1 lodine species. Iodox is capable of an RF of $10^{5}$.

(a) Trademark of Sud Chemie A.G., Munich, Germany. 
IABLE 4. Processes for Iodine Capture in an $\operatorname{FRP}^{(a)}$

\section{Process}

Caustic scrubbing

Mercurex $\left(\mathrm{Hg}\left(\mathrm{NO}_{3}\right)_{2}-\mathrm{HNO}_{3}\right.$ scrubbing)

Iodox (22 $\mathrm{M} \mathrm{HNO}_{3}$ scrubbing)

Electrolytic scrubbing

Organic 1 iquid scrubbing

Purex silver reactor $(d)$

Silver zeolites

AC- $6120^{\oplus}$

Organic solids

$\frac{\text { Retention Factor }(b)}{10 \text { to } 10^{3} \text { (for } I_{2} \text { ) }}$
$10^{3}$ to $10^{4}$ (practical $10^{2}$ )
$10^{5}$
100 to 600
$10^{4}$
$10^{3}$ (practical $10^{2}$ )
$10^{4}$ (c)
$>10^{4}$
$10^{4}$

(a) Burger and Scheele (1983).

(b) Retention factor (Amount input divided by amount output)

(c) Recent work by Burger, Scheele, and Matsuzaki at PNL indicated that RF's $>10^{5}$ are possible for $\mathrm{CH}_{3}$ I capture.

(d) Developed for ${ }^{13 l_{I}}$ retention and has not been demonstrated for ${ }^{129}$ I retention. 
The capture technology currently used in operating FRP's in the U.S. is the Purex "silver reactor" (NCRP 1983). It should be emphasized that the "silver reactor" was developed only to retain ${ }^{131}$ I for the relatively short time period required until it decayed to insignificance. No development or testing has been done for the "silver reactor" for ${ }^{129}$ I retention (Brown, Christian and Thomas 1983); in fact, when the Hanford "silver reactors" were analyzed for ${ }^{129}$ I after several years of operation, none was found (Strachan 1978). The WAK facility in the Federal Republic of Germany employs $A C-6120^{\circledR}$. The Windscale TBP plant in the U.K., and UP2 and HAO at La Hague, France al1 use caustic scrubbers. The DFR at Dounreay in the U.K. uses Mercurex. The Tokai Mura plant in Japan uses a caustic scrubber as the primary trap and silver zeolite as a secondary trap (NCRP 1983).

The Al1 ied General Nuclear Services (AGNS) Plant had been designed to use Mercurex as the primary trap and silver zeolite as the secondary trap (NCRP 1983). Exxon had planned to use two silver sorbent beds in series at its proposed Purex Plant (Exxon 1978).

\section{RADIOIODINE MONITORING}

Measurement of radioiodine in the gas streams of an FRP is a complex problem for which no fully satisfactory method is currently available for the concurrent measurement of a 11 iodine radioisotopes present. Methods do exist which al low measurement of the radioiodines, but only ${ }^{13}$ I can be measured on a real-time basis. Potential methods exist which may remedy the problem. This section discusses factors which must be considered for iodine monitoring, reviews current monitoring practices in an FRP, and identifies current and potential methods for measurement of iodine and its isotopes.

\subsection{MONITORING CONSIDERATIONS}

In addition to the many factors discussed in Section 6, the monitoring of radioiodine could be further complicated by the many isotopes of iodine generated during fission. Most are very short-lived and decay to insignificant levels shortly after discharge of the irradiated fuel from the 
reactor. A few days out of reactor, there will be only three isotopes of iodine present in significant amounts, stable ${ }^{127} \mathrm{I},{ }^{129} \mathrm{I}$ and ${ }^{131} \mathrm{I}$. After about 200 days, ${ }^{129} \mathrm{I}$ is the predominant radioactive species, and after 250 days, on $1 y{ }^{127} \mathrm{I}$ and ${ }^{129} \mathrm{I}$ remain (in an approximate $1: 5$ ratio). Thus, for short-cooled fuel (<250 days) both ${ }^{129} I$ and ${ }^{13 I_{I}}$ w 111 be the radioiodines present; for longer-cooled fuels, on $1 y^{129} \mathrm{I}$ will remain.

A good monitoring method should be capable of determining the radioiodine independently of chemical species, be able to measure multiple iodine isotopes for the short-cooled fuel and ${ }^{129}$ I for the longer-cooled fuel, and be able to operate in a potentially hostile chemical environment.

The primary path to the atmosphere for iodine in an FRP is via the DOG, and monitoring of iodine concentrations downstream of the iodine collector would allow detection of a major upset in normal conditions. Since the concentrations in the DOG stream are much greater than in the stack, a less sensitive method might be applied which would al low for real-time analysis.

\subsection{MONITORING STRATEGIES}

Two potential strategies exist for determination of iodine in the gas streams within an FRP. The first, and preferable one, is to determine the radioiodine concentrations in the gas on a real-time basis. The second alternative is to preconcentrate the iodine until a measurable amount has been collected.

It is possible to directly monitor ${ }^{13 I}$ I in gas streams, but not ${ }^{129}$ I. Thus radioiodine could be continuously monitored in the gas streams only if the fuel were less than approximately 250 days old. The possibilities and problems associated with in-line monitoring will be discussed in the following sections.

\subsection{CURRENT MONITORING TECHNIOUES}

The methods which have been used for measurement of low concentrations of iodine in the stack gas have involved collection of iodine in sorbents such as caustic solution, charcoal, or silver-containing materials like 
$A C-6120^{\circledR}$ or silver zeolites $(A g Z)$. These materlals are then analyzed using 1 ow energy photon spectroscopy (LEPS) or gamma counting. If fuels of short cooling period were processed, the detection of ${ }^{13}{ }^{1}$ I could be done by one of the above methods or by use of a $\gamma$ monitor that detects, in real time, the total gas radioactivity. In the past, periodic measurement of ${ }^{131_{I}}$ samples in the laboratory has been considered sufficient and has been more accurate for small releases than in situ methods. Unfortunately, the sample integration time of several days does not permit timely detection of a major upset in operation. In the U.S., plants designed to use the Purex process have provisions for collecting samples before and after the silver bed and before and after particle filters.

At the time the Hanford Purex facility stopped operation in 1972, a combined caustic scrub followed by a charcoal filter was employed as a stack gas sampler. This procedure is an improvement over the monitoring scheme presented in the Purex Manual (HAPO 1955). The caustic was continuously monitored for ${ }^{13 l_{I}}$ using a $\mathrm{NaI}(T 1)$ detector. After a nominal 72-hour change-out, the caustic and charcoal were gamma counted for ${ }^{131}$ I. Intermittent samples using caustic scrubbers were taken at other points in the plant including the ventilation air.

With the restart of the Hanford Purex facility, the system has been modified (RHO 1980). Gaseous effluent samples are collected at $1 \mathrm{~L} / \mathrm{sec}$ $(2 \mathrm{cfm})$ in a standard triethylenediamine (TEDA)-impregnated charcoal cartridge for one week. Analysis for ${ }^{129}$ I is performed using scintillation counting and a multichannel analyzer. (a) Ten percent of the concentration guide for Uncontrol led Areas (Table 3) can be detected. Provisions are made for sampling the off-gas streams from other parts of the plant including the sample gallery hoods, and the process vent 1 ine.

In addition, a special stack monitor constructed by Eberl ine Instruments Company for particulates, iodine, and noble gases is being tested at

(a) The cartridge could also be analyzed for ${ }^{131}$ I should it become necessary. 
Hanford. A carbon filter is part of the package, and separate detectors are used to monitor ${ }^{129} \mathrm{I}$ and ${ }^{131} \mathrm{I}$. Al though the monitor has been shown to be sensitive to ${ }^{129} \mathrm{I}$, it has not been proven that it can measure th is nuclide in the relatively high background radiation from other radionuclides present in FRP gaseous effluent.

The Savannah River Plant (SRP) also uses charcoal samplers (5\% TEDA on coconut she 11 charcoal) at the 125-ft level on the stack. (a) The sample flow rate is $2.5 \mathrm{~L} / \mathrm{sec}(5 \mathrm{cfm})$. Two canisters are $\mathrm{placed}$ in series and monitored with gamma counters. Intermittent samples are also taken with an activated charcoal filter (MSA 13724A) and with aluminum silicate impregnated with silver nitrate. A periodic check of the charcoal canisters is made for ${ }^{129}$ I using thermal neutron activation. Occasional checks have been made for organic lodides, but very 1 ittle has been found. There is no capability to sample the DOG directly.

At the SRP the fuels being processed are at least 200 days out of reactor. At 200 days, the ${ }^{131}$ I content has decreased to $3 \times 10^{-8}$ of the amount present at the time of reactor shutdown.

The Idaho Falls Separation Plant also uses a charcoal sampler. It is backed up with a silver zeolite cartridge. The samples are collected twice month $1 y$ and counted. The results are avallable about 2 days after collection. Only the main stack is monitored (Fernandez et al. 1979).

The proposed Exxon reprocessing facility design called for a $2 \mathrm{~L} / \mathrm{sec}$ (4 cfm) gas stream from the stack which would be split into two streams. One would be monitored for $\alpha$, the other for $\beta-\gamma$-particulate-iodine-krypton. The particulate filter was to have a $0.3 \mu \mathrm{m}$ pore size at an efficiency of 99.97\%. The ${ }^{131}$ I on the iodine absorber (presumably charcoal) is analyzed using a single-channel $\gamma$ analyzer, and a 4-hr counting time. The system should detect a concentration of $4 \mathrm{pCi} / \mathrm{m}^{3}$ at the $95 \%$ confidence 1 evel from a sample of several hundred $\mathrm{m}^{3}$ of gas. A correction must be made for the

(a) Private communication from D. Orth, SRP, to L. L. Burger, PNL, 11/4/83. 
${ }^{85} \mathrm{Kr}$ coll lected on the sampler. The provision for ${ }^{129} \mathrm{I}$ measurement consists of removing the iodine filters and counting in the laboratory (Exxon 1978). A1 though this equipment has not been used, the description probably represents the state-of-the-art.

In the AGNS plant, it was planned to pass a portion of the main stack effluent either through a silver zeolite bed for total lodine measurement or through an activated charcoal filter to determine the ${ }^{131} \mathrm{I} /{ }^{129} \mathrm{I}$ ratio. Cellulose glass fiber filter paper was to be used to collect particulates for analysis. The zeolite bed was to be continuously monitored using a $\mathrm{NaI}(\mathrm{Tl})$ detector.

Both carbon and silver-impregnated absorbers are used in Europe. In Germany the silver nitrate impregnated silica, $A C-6120^{\circledR}$, is proposed as an absorber for monitoring. The sample is $\gamma$-counted directly giving a sensitivity of $10^{-4} \mu \mathrm{mol}\left(2 \mathrm{pCi}\right.$ ) ${ }^{129} \mathrm{I} / \mathrm{mL}$ AC- $6120^{\circledR}$ (Wilhel $\mathrm{m}$, Furrer and Schul tes 1976).

In summary, the current monitoring practice uses solid absorbers that may represent 1 to $1000 \mathrm{~m}^{3}$ of gas over a sample time that ranges from a few days to a few weeks. Samples are counted directly or after thermal neutron activation. The larger sample volumes provide for enough sensitivity to enable detection of ${ }^{129} \mathrm{I}$ and ${ }^{131}$ I concentrations 1 isted in existing U.S. NRC and DOE guides. An on-line monitor for simultaneous real-time detection of ${ }^{129} \mathrm{I}$ and ${ }^{13 l}$ I has been instal led in at least one case, but its successful operation has not been demonstrated in the presence of other radionuclides normally found in the off gases of an FRP.

\subsection{METHODS FOR RADIOIODINE MEASUREMENT}

The optimum iodine monitor or measurement system is one which will provide quantitative information on the concentration of particular iodine isotopes and chemical forms present in the gas stream. Many methods have been developed for measurement of radioiodine isotopes. Iodine-131 is easily measured by gamma analysis while ${ }^{129} \mathrm{I}$ is more difficult to measure because of its low specific activity. Table 5 lists methods which have been developed for measurement of ${ }^{129} \mathrm{I}$. Most have been developed for determining 
IABLE 5. Sensitivity of Analytical Techniques for ${ }^{129}{ }^{(a)}$

\begin{tabular}{|c|c|}
\hline Method & ${ }^{129}$ I detection 1 imit, $\mu \mathrm{mol}{ }^{(b)}$ \\
\hline Liquid scintillation $(c)$ & $2 \times 10^{-5}$ \\
\hline Gas flow proportional counting $(c)$ & $2 \times 10^{-5}$ \\
\hline Low level $\beta^{-(c)}$ & $2 \times 10^{-6}$ \\
\hline$\gamma-r$ ay and $x-r$ ay & \\
\hline Ge detector $(\gamma)(d)$ & $2 \times 10^{-5}$ \\
\hline $\operatorname{NaI}(T I)$ detector $(\gamma+x-$ ray $)(e)$ & $2 \times 10^{-6}$ \\
\hline Neutron activation $(f)$ & $5 \times 10^{-11}$ \\
\hline Mass spectrometry $(f)$ & $2 \times 10^{-11(g)}$ \\
\hline Laser fluorescence $(h)$ & \\
\hline Wide band & $2 \times 10^{-8} / \mathrm{cm}^{3}$ \\
\hline Single band & $2 \times 10^{-9} / \mathrm{cm}^{3}$ \\
\hline Gas chromatography $(i)$ & \\
\hline $\mathrm{I}_{2}$, electron capture detector (ECD). & $4 \times 10^{-2(j)}$ \\
\hline $\mathrm{CH}_{3} \mathrm{I}, \mathrm{ECD}$ & $1 \times 10^{-6(j)}$ \\
\hline $\mathrm{CH}_{3} \mathrm{I}$, photonization detector (PID) & $4 \times 10^{-5(k)}$ \\
\hline
\end{tabular}

(a) Goles et al. (1981), except as noted.

(b) $1 \mu \mathrm{mol}{ }^{129} \mathrm{I}=22 \mathrm{nCr}$

(c) Measures total radiolodine

(d) Radioisotope sensitive

(e) Inadequate resolution to measure ${ }^{129} \mathrm{I}$ when ${ }^{131} \mathrm{I}$ present

(f) Iodine isotope sensitive

(g) Elmore et al. (1980).

(h) Developed for detection of ${ }^{129} \mathrm{I}_{2}$

(i) Measures tota 1 iodine

(j) Fernandez et al. (1983)

(k) Scheele, Burger, and Matsuzaki (1983). 
${ }^{129}$ I in the environment and have not been tested for ${ }^{129} \mathrm{I}$ detection in FRP gas streams. Many of the methods 1 isted are al so useful for ${ }^{131}$ I measurement and will have the same detection 1 imit for ${ }^{13}{ }^{1}$ I as for ${ }^{129}$ I with the exception of gamma counting as discussed later. For example, those that measure mass directly ( $\mu \mathrm{mols}$ ) will have the same sensitivity in terms of mass for either lodine isotope.

Recent discussions on iodine monitoring can be found in McKay, Miquel, and White (1982) and Taylor (1982).

\subsubsection{Radiometric Techniques}

The first four methods in Table 5 are radiometric techniques which measure the radioemissions of ${ }^{129} \mathrm{I}$ and ${ }^{131} \mathrm{I}$. Table 6 presents the radioemissions of ${ }^{129} \mathrm{I}$, and Table 7 presents the radioemissions of ${ }^{131} \mathrm{I}$. Both isotopes have the xenon $x$-rays present in their spectrum. Thus, if both isotopes are present, the detector must be able to resolve the different radiations in order to measure the low specific activity ${ }^{129} \mathrm{I}$.

\subsubsection{Liquid Scintillation Counting}

When measuring a particular isotope using 1 iquid scintil lation counting, the sample must be in intimate contact with the liquid scintillator. This means that the lodine-containing sample must be dissolved in the scintillation cocktai1. Thus, for accurate measurement of either ${ }^{13} I_{I}$ or ${ }^{129}$ I this method requires chemical separation of the iodine. Methods do exist for determination of two radionuclides simultaneous $1 y$; however, the range of nuclide ratios for ${ }^{131}$ I and ${ }^{129}$ I that could easily be determined was not found. Extensive sample preparation is required, and the method is not adaptable to real-time measurement of radioiodine in the gas streams of an FRP.

\subsubsection{Proportional and Low-Leve] $\beta$-Counting}

Gas flow proportional and 1 ow-leve $1 \beta$-counting are both applied to solid samples and can be used to measure ${ }^{129}$ I and ${ }^{131}$ I captured on a sol id sorbent such as charcoal or AgZ. However, with both of these sorbents se $1 \mathrm{f}$-absorption could be a problem. These methods would be ineffective as 


$\begin{array}{ccc}\text { IABLE 6. } & { }^{129} \text { I Radioemissions (Kocher 1981) } \\ \text { Radiation } & \text { Energy, KeV } & \text { Intensity, \% } \\ \beta^{-} & 152 & 100 \\ \text { Xenon X-rays } & 39.6 & 7.52 \\ K_{\alpha} & 29.78 & 37.0 \\ K_{\alpha} & 29.46 & 20.0 \\ K_{B} & 33.6 & 11.0 \\ K_{B} & 34.4 & 2.3 \\ K_{2} & 4.1 & 8.2\end{array}$




\begin{tabular}{|c|c|c|}
\hline Radiation & Energye KeV & Intensity, \% \\
\hline \multirow[t]{5}{*}{$\beta^{-}$} & 248 & 2.1 \\
\hline & 304 & 0.63 \\
\hline & 334 & 7.36 \\
\hline & 606 & 89.3 \\
\hline & 807 & 0.39 \\
\hline \multirow[t]{9}{*}{$\gamma$} & 80.2 & 2.62 \\
\hline & 177.2 & 0.26 \\
\hline & 284.3 & 6.05 \\
\hline & 325.8 & 0.25 \\
\hline & 364.5 & 81.2 \\
\hline & 503.0 & 0.36 \\
\hline & 637 & 7.26 \\
\hline & 642.7 & 0.22 \\
\hline & 722.9 & 1.80 \\
\hline \multicolumn{3}{|c|}{ Xenon $x$-rays } \\
\hline $\mathrm{k}_{\alpha_{1}}$ & 29.78 & 2.50 \\
\hline $\mathrm{k}_{\alpha_{2}}$ & 29.46 & 1.35 \\
\hline$K_{B_{1}}$ & 33.6 & 0.72 \\
\hline$K_{\beta_{2}}$ & 34.4 & 0.17 \\
\hline$L$ & 4.1 & 0.55 \\
\hline
\end{tabular}


real-time monitors because of the high background radiation levels present in the effluent stream.

\subsubsection{Gamma-Ray and X-Ray Detection}

Gamma-ray and $x-r a y$ analysis have been the methods typical11y employed to determine ${ }^{129} \mathrm{I}$ and ${ }^{131} \mathrm{I}$. The fodine is usua $11 \mathrm{y}$ preconcentrated in a trapping solution or solid sorbent until a detectable quantity is present. Gamma counting of ${ }^{131}$ I can be done on a real-time basis. One procedure used at Hanford was to collect fodine in a caustic scrubbing solution which was then monitored by a $\mathrm{NaI}(\mathrm{Tl})$ scintill 1ation detector. To measure ${ }^{129} \mathrm{I}$ it must first be preconcentrated. For fuels with 1 ow ${ }^{131}$ I content the NaI(TI) detector provides adequate resolution to determine ${ }^{129} \mathrm{I}$. However, for shorter-cooled (<200 days) fuels low energy photon spectroscopy (LEPS) using either a Germanium or a $\mathrm{Ge}(L i)$ detector is required to resolve the $39.6 \mathrm{keV} \gamma$ of ${ }^{129} \mathrm{I}$ from the $X e x$-rays, compton scattering and bremsstrahlung photons produced from $\beta$ and $\gamma$ radiation of higher energy. However, the latter two detectors have a detection 1 imi.t for ${ }^{129}$ I that is a factor of 10 greater than that of the NaI(TI) detector.

For short-cooled fuels it is necessary to use LEPS in order to measure both isotopes. The intensity of the ${ }^{129} \mathrm{I} Y$ is $7.5 \%$ (see Tab1e 6) compared to the $81 \%$ intensity (see Table 7 ) of the principal ${ }^{13 l_{I}} \gamma$. Therefore, with germanium detectors (LEPS), the detectability of ${ }^{13}{ }^{1}$ I is a factor of 10 better than for ${ }^{129} \mathrm{I}$. With a $\mathrm{NaI}(\mathrm{Tl})$ crystal the $x$-rays and $\gamma$-ray of ${ }^{129}$ I combine into one broad peak with an intensity of $78 \%$ or nearly the same intensity as the principal $\gamma$ for ${ }^{13 I^{I}} \mathrm{I}$. Thus, the detection 1 imit for ${ }^{129}$ I using a $\mathrm{NaI}(T 1)$ detector is the same as for ${ }^{131} \mathrm{I}$ on a curie basis, but the ratio of the detection 1 imits $\left({ }^{129} \mathrm{I} /{ }^{131} \mathrm{I}\right)$ is about $10^{9}$ on a mole basis.

Because of the high background radiation from other radionuclides present in the FRP gas streams, the LEPS method is not applicable to rea itime analysis of ${ }^{129} \mathrm{I}$. Fernandsa, Hiviallus, and Burr (1983) reported a method which they consider a continuous ${ }^{14} \mathrm{C},{ }^{129} \mathrm{I}$, and ${ }^{85} \mathrm{Kr}$ monitor. This method involves removal of the ${ }^{85} \mathrm{Kr}$ from the sample stream prior to passing the sample stream through a charcoal collector for iodine. The amount of 
${ }^{129}$ I collected is then continuously monitored using an NaI(T1) detector. The removal of the ${ }^{85} \mathrm{Kr}$ reduces the radioactive background to a level where the ${ }^{129}$ I can be measured. The concentration of ${ }^{13}{ }$ I in the sample stream must, of course, be reasonably 1 ow.

The different techniques available for preconcentrating or collecting the lodine for analysis include the use of both aqueous and solid sorbents. The aqueous solutions which are effective for al 1 of the chemical types of iodine are mercuric nitrate-nitric acid $\left(\geqslant 8 \mathrm{M} \mathrm{HNO}_{3}\right)$ and $22 \mathrm{M} \mathrm{HNO}_{3}$. Caustic or thiosulfate solutions are often used for routine gas sampling for iodine; however, they do not trap organic iodides. Solid sorbents include activated charcoal, silver zeolite, and $A C-6120^{\circledR}$. The latter has been demonstrated by Wilhelm, Furrer, and Schultes (1976) to al low detection of $10^{-4} \mu \mathrm{mol} \mathrm{I} / \mathrm{mL}$ $A C-6120^{\circledR}\left(2 \mathrm{pCi}{ }^{129} \mathrm{I} / \mathrm{mL}\right.$ AC-6120 ) using LEPS.

\subsubsection{Neutron Activation Analysis}

Neutron Activation Analysis is one of the most sensitive of the analytical procedures for ${ }^{129} \mathrm{I}$. It is closely related to the radiometric analysis techniques in that radioemissions from the activation products are used to determine the amount of ${ }^{129} \mathrm{I}$ and ${ }^{127} \mathrm{I}$ present in the samp $1 \mathrm{e}$. The process cannot be applied to real-time analysis and the turn-around time is at least a couple of days. The method also requires chemical separation to obtain accurate analyses and is expensive (several hundred dol 1 ars per sample).

\subsubsection{Mass Spectrometry}

Mass spectrometry (MS) a 11 ows the detection of very low levels of ${ }^{129}$ I and possibly could be used for real-time analysis. Stoffels (1982) describes a technique using negative ion mass spectrometry to analyze $10^{-11}$ umol ${ }^{129} \mathrm{I}$. Others (Ruck1idge et a 1. 1981) have used tandem accelerators to measure ${ }^{129} \mathrm{I}$. Fernandez et a 1 . (1983) describe the development of a method where the iodine is first purified using a gas chromatographic (GC) technique followed by negative ion mass spectrometry. Refinement of this GCMS technique could eliminate the potential problems with real-time 
mass spectrometer analysis. Problems associated with this technique include standardization, ionization efficiency, and the effects of $\mathrm{NO}_{x}$ on the ionizer.

Discussion with Stoffels suggests that mass spectrometry has a potential for use in a real-time iodine monitor. An additional advantage is that it provides a method for direct determination of the isotopic content of the iodine. One potential disadvantage is the high cost of the equipment.

\subsubsection{Laser Spectroscopic Methods}

These methods are sensitive to the isotopic composition of the $I_{2}$ molecule. The methods as developed measure ${ }^{129} \mathrm{I}_{2}$ and no other isotopic or chemical species.

The first method (Goles et a 1. 1981) involves 1 aser fluorescence spectroscopy. The sample is excited by irradiation with a laser and the fluorescence of the ${ }^{129} \mathrm{I}_{2}$ measured. Both single-band and broad-band fluorescence have been used. In the latter, species which are not of interest are placed in the cavity to remove their absorption 1 ines and subsequently the sample excited with the remaining photons. In additional discussions Goles indicated that the process is not easily adaptable to the rea 1-time measurement of iodine in the FRP's stack gas.

The second method involves laser intracavity absorption. In this method the sample gas is placed in the laser cavity. A fluorescence cell containing the species of interest is placed in the resulting 1 ight beam. The fluorescence of this cell is monitored providing a measurement of the iodine species of interest since the fluorescence intensity will be dependent on 1 ight reaching it from the sample cel 1 .

Unfortunately, these methods are chemical and isotopic species sensitive and have not been developed to the state where they could detect al 1 the iodine species in an FRP's gas stream. In addition, $\mathrm{NO}_{x^{\prime}}$ present in nearly all FRP off-gas streams, interferes. Goles feels that the 1 aser method is really not feasible for application in an FRP. 


\subsubsection{Gas Chromatography}

Fernandez et a1. (1983) describe a gas chromatography (GC) method for the determination of iodine as $\mathrm{I}_{2}$ and as $\mathrm{CH}_{3} \mathrm{I}$. Using an electron capture detector (ECD) the method was able to measure $1 \times 10^{-6} \mu \mathrm{mol} \mathrm{CH}_{3} \mathrm{I}$ and $4 \times 10^{-2} \mu \mathrm{mol} \mathrm{I}$ as $\mathrm{I}_{2}$. Fernandez, McManus, and Burr (1983) describe a method for converting $\mathrm{I}_{2}$ to $\mathrm{CH}_{3} \mathrm{I}$ by reaction with $\mathrm{Bi}\left(\mathrm{CH}_{3}\right)_{3}$. Possible combination of the two methods might allow detection of total lodine as $\mathrm{CH}_{3}$ I. Scheele, Burger, and Matsuzaki (1983) used a gas chromatograph with an auto sampling valve and a photoionization detector to continuously determine the $\mathrm{CH}_{3} \mathrm{I}$ concentration in a simulated dissolver off-gas (DOG) stream. The detection 1 imit was $4 \times 10^{-5} \mu \mathrm{mol} \mathrm{CH}_{3} \mathrm{I}$.

Assuming a $1-\mathrm{mL}$ sample, the detection $1 \mathrm{imit}$ for the ECD method is $1 \times 10^{-3} \mu \mathrm{mol} \mathrm{CH} \mathrm{CH}_{3} \mathrm{I}$ L. Though this is too high for detection of the Concentration Guide for ${ }^{129} \mathrm{I}$ of $9 \times 10^{-7}$ umol ${ }^{129} \mathrm{I} / \mathrm{L}$ (see Table 3), it might be useful as a real-time monitor immediately after the final lodine trap of the DOG treatment system. This gas stream has not yet been diluted by the large flow of ventilation air at the plant stack.

\subsubsection{Qther Methods}

B. L. Taylor (1982) gives two additional methods which are nonisotopespecific: emission spectroscopy using a plasma source (ICP) and piezoelectric detection. ICP has a detection 1 imit of 0.5 ppm as aqueous ammonium iodide (Kirkbright, ward and West 1973). This method has not been applied to direct measurement of a gas stream but might possibly have application for ${ }^{129} \mathrm{I}$ in plant streams. Piezo-electric measurement, based on unpublished work of Taylor, is probably too insensitive for ${ }^{13} l_{I}$ in relation to the regulatory guidelines. It is not applicable to organic iodides, and other species in the gas streams will interfere with iodine detection. A nonisotope-specific method, such as this, requires knowledge of lodine introduced as an impurity with process chemicals. 


\subsection{MONITORING FOR ADVANCED FUELS}

The techniques required for monitoring radiolodine released during the reprocessing of advanced (high-exposure) fuels should not differ drastically from those used for monitoring effluents from reprocessing of LWR fuels. If the content of ${ }^{129}$ I calculated for LMFBR fuels, (Table 2) is representative of advanced fuels, the concentration of ${ }^{129} \mathrm{I}$ in the gas streams wi11 increase by about $30 \%$ above those associated with LWR fuels. Hence, its detection would be only slightly easier - al 1 other factors being equal.

\subsection{MONITORING ADEOUACY}

Real-time radioiodine monitors currently in use are gamma and $x$-ray counters. The use of these instruments to monitor al1 the radioiodine isotopes on a real-time basis is complicated by the number and amounts of possible iodine radioisotopes and the nature of their respective radioemissions. The analysis is made even more difficult by the high background radiation levels from other radionuclides in the gas streams.

The amount of each radioiodine is in turn dependent on the age of the fuel processed (Table 1). For fuels less than 200 days old, ${ }^{129} \mathrm{I}$ and ${ }^{13 l} \mathrm{I}$ wil 1 both be present, and for fuels older than 250 days, only ${ }^{129}$ I will be present in sufficient quantity to be important. For the shorter-cooled fue $1 \mathrm{~s}$ the presence of ${ }^{131}$ I comp 1 icates the analysis for ${ }^{129}$ I by increasing the background and by contributing to the $X e x$-rays being monitored. However, within 1 imits it is possible to measure both radioisotopes using LEPS. On the other hand, ${ }^{131}$ I can be measured on a real-time basis either quantitatively or semi-quantitatively, thus al lowing the detection of offnormal performance of the iodine control system. For the older fuels the radiation background in situ is too great to al low direct, real-time measurement of ${ }^{129} \mathrm{I}$. Thus the gas stream must be sampled by passing through an iodine sorber until a detectable amount has been collected. At this time the sampler can be removed for gamma and $x$-ray counting in a location with a low radiation background. 
Whether current technologies are adequate for radioiodine monitoring in the gas streams of an FRP is dependent on the definition of "adequate". If the objective of the monitoring is to determine quantitatively the amounts of the radiolodine isotopes released to the environment for a specific time period; e.g., $8 \mathrm{hr}$, the monitoring methods are adequate. If the objective is to determine immediately, qualitatively or semiquantitatively whether an off-normal event has occurred in the operation, current monitoring techniques are adequate for fuels cooled $<150$ days where ${ }^{131}$ I can be measured, but inadequate for fuels cooled $>250$ days where ${ }^{129}$ I is the only radioiodine present.

\section{CONCLUSIONS}

No irradiated reactor fuel aged less than 10 years, post-reactor, need be processed prior to the year 2000. In such aged fuel, ${ }^{129} \mathrm{I}$ is the on $1 y$ radioiodine present. Guides and standards for control of exposure to ${ }^{129} \mathrm{I}$ are general $1 \mathrm{y}$ based on 1 imiting thyroid radiation doses to $15 \mathrm{rem} / \mathrm{yr}$ for occupationally exposed persons and $1.5 \mathrm{rem} / \mathrm{yr}$ for members of the public. Maximum permissible air concentrations for ${ }^{129} \mathrm{I}$ have been derived from these dose 1 imits and promulgated by the NRC and the DOE. Two newer and more restrictive 1 imits have been specified by the U.S. EPA in 40 CFR 190; viz., 1) a thyroid dose 1 imit of 75 mrem $/ y r$ for members of the public from a 11 phases of the uranium fuel cycle, and 2) an ${ }^{129}$ I release rate 1 imit of $5 \mathrm{mCi}$ per $\mathrm{GW}(e)-y r$. The second of these two is more restrictive than the first. The release rate 1 imit requires a long-term average RF value of at least 200 in an FRP reprocessing aged LWR fuels, which contain about $1 \mathrm{C} i$ ${ }^{129} \mathrm{I}$ per $\mathrm{GW}(e)-y r$.

Several technologies are avallable for the removal of radioiodines from the gaseous effluents of an FRP. The recommended methods use the silver-based sorbers because of their high sorption efficiencies and convenience of use. The technologies have been demonstrated but not optimized to minimize cost. The chemistries of the processes are not completely understood. They require further study to al low process design and 
operation to cover al 1 possible contingencies and to minimize use of silver, an expensive and valuable resource.

The current state-of-the-art for radiolodine monitoring in the gaseous eff 1 uents at an FRP is to preconcentrate the lodine on an absorber to a detectable level and either measure $1 \mathrm{t}$ in $\mathrm{place}$ by in situ gamma counting or remove the sorbent to the laboratory, and radiometrically determine the radiolodine concentration. For short-cooled fuels LEPS is the preferred method since both ${ }^{129} \mathrm{I}$ and ${ }^{13} 1_{\text {I }}$ can be measured. For fuels which have been out-of-reactor for $>250$ days $\mathrm{NaI}(\mathrm{Tl})$ detectors would suffice for measurement of ${ }^{129}$ I.

There are currently no methods which can simultaneously measure al 1 of the radiolodine isotopes on a real-time basis. It is currently possible to monitor ${ }^{131}$ I on a real-time basis, but not ${ }^{129}$ I. Future possibilities for real-time monitors include mass spectrometry, gas chromatography, and induction coupled plasma atomic spectroscopy. Most of these methods involve the use of expensive instruments. Extensive development would be required for any other methods.

The effect of reprocessing advanced fuel types is difficult to quantify at this time because of some question as to the exact amount of iodine that will be produced. But the ${ }^{129}$ I content per tonne increases with fuel exposure and the fission yield of ${ }^{129}$ I is significantly higher for ${ }^{239} \mathrm{Pu}$ than for ${ }^{235} \mathrm{U}$. Since the yield of other nuclides also changes with changes in fuel type and exposure, the spectrum of interfering background radiation could change either favorably or unfavorably in relation to radiometric measurement methods. However, it appears that eff 1 uents from facilities reprocessing advanced fuels can be monitored for ${ }^{129}$ I using current and presently envisioned techniques with no more difficulty than encountered when monitoring effluents from reprocessing of LWR fuels for ${ }^{129}$ I. 


\section{REFERENCES}

Brown, R. A., J. D. Christian and T. R. Thomas. 1983. Airborne Radionuclide Waste Management Reference Document. ENICO-1133, Exxon Nuclear Idaho Co., Inc., Idaho Falls, Idaho.

Burger, L. L., and R. D. Scheele. 1983. The Status of Radieiodine Control for Nuclear Fuel Reprocessing Plants. PNL-4689, Pacific Northwest Laboratory, Rich 1 and, Washington.

10 CFR 20, 1983. Code of Federal Regulations, Title 10, Part 20, Appendix B, U.S. Nuclear Regulatory Commission, Washington, D.C.

Croff, A. G. 1980. A User's Manual for ORIGEN2 Computer Code. ORNL/TM-7175, Oak Ridge National Laboratory, Oak Ridge, Tennessee.

Dillman, L. T., and F. C. Von der Lage. 1975. Radionuclide Decay Schemes and Nuclear Parameters for Use in Radiation-Dose Estimation NM/MIRD Pamphlet No. 10, Society of Nuclear Medicine, New York, New York.

Elmore, D., et a1. 1980. "Determination of ${ }^{129}$ I Using Tandem Accelerator Mass Spectrometry." Nature 286:138-140.

Exxon. 1978. Nuclear Fue l Recovery and Recycling Center Preliminary Safety Analys is Report. XN-FR-32, Vol. 5, Section 8.6, Exxon Nuclear Co., Inc., Bel levue, Washington.

Fernandez, S. J., G. D. Pierce, D. C. Hetzer, and B. G. Motes. 1979. Methods Evaluation for the Continuous Monitoring of Carbon-14, Krypten-85, and Iodine-129 in Nuclear Fuel Reprocessing and Waste Solidification Facility Off-Gas. ICP 1187. Idaho National Engineering Laboratory, Idaho Fal1s, Idaho.

Fernandez, S. J., et a1. 1983. Determination of Low Specific Activity Iodine-129 off-Gas Concentrations by GC Separation and Negative Ionization Mass Spectrometry. ENICO-1134, Exxon Nuclear Idaho Company, Inc., Idaho Fal1s, Idaho.

Fernandez, S. J., G J. McManus, and J. R. Burr. 1983. Evaluation of a Continuous ${ }^{14} \mathrm{C}_{2}{ }^{129} \mathrm{I}$, and ${ }^{85} \mathrm{Kr}$ Monitor Under Dissolver Off-Gas Conditions. ENICO-1135. Exxon Nuclear Idaho Company, Inc., Idaho Fal 1s, Idaho.

Goles, R. W., R. C. Fukuda, M. W. Cole and F. P. Brauer. 1981. "Detection of Iodine-129 by Laser-Induced F1uorescence." Anal. Chem. 53:776-778.

HAPO. 1955. Purex Technical Manual. HW-31000, Hanford Atomic Products Operation, Richland, Washington.

Hower, R. B., and D. T. Pence. 1978. Identification of Iodine-129 Sources, Concentrations, Contaminant Levels and Radjojodine Monitoring Techniques in LWR Reprocessing Operations. SAI/00979-1, Science App 1 ications, Inc., San Diego, California. 
Kirkbright, G. F., A. F. Ward and T. S. West. 1973. "Atomic Emission Spectrometry with an Induction-Coupled High Frequency Plasma Source. The Determination of Iodine, Mercury, Arsenic, and Selenium." Anal. Chim. Acta. 64:353-362.

Mckay, H. A. C., P. Miquel and I. F. White. 1982. "Management Modes for Iodine-129." In Management Modes for Iodine-129, eds. W. Hebel and G. Cottone, Harwood Academic Publ ishers, New York.

NEA. 1980. Radiological Sionificance and Management of Tritium, Carbon-14, Krypton-85, Iodine-129 Arising from the Nuclear. Fuel Cycle. Nuclear Energy Agency, Organization for Economlc Cooperation and Development.

NCRP. 1983. Iodine-129: Evaluation of Releases from Nuclear Power Generation, NCRP Report 75, National Council on Radiation Protection and Measurements, Bethesda, Maryland.

RHO. 1980. Purex Technical Manual. RHO-MA-116, Rockwel 1 Hanford Operations, Richland, Washington.

Ruck1 idge, J. C., et a1. 1981. "Rare Isotope Detection with Tandem Accelerators." Nuc. Inst. and Meth. 191:1-9.

Schee 1e, R. D., L. L. Burger and C. L. Matsuzaki. 1983. Methyl_Iodide Sorption by Reduced Silver Mordenite. PNL-4489, Pacific Northwest Laboratory, Richland, Washington.

Stoffe1s, J. J. 1982. "Measurement of Iodine-129 at the Femtogram Level by Negative Surface Ionization Mass Spectrometry." Radiochem. Radioanal. Letters. 55(2):99-106.

Strachan, D. M. 1978. Analysis of the Dissolver Silver Reactors from Hanford's Purex Plant. RHO-ST-2, Rockwell Hanford Operations, Richland, Wash ington.

Taylor, B. L. 1982. "The Monitoring of I-129 in Reprocessing Plant Effluents." Seminar on Iodine Removal from Gaseous Effluents in the Nuclear Industry. CEC Mol, Belgium.

Trevorrow, L. E., G. F. Vandergrift, V. M. Kolba and M. J. Steindler. 1983. Compatibility of Technologies with Regulations in the Waste Management of $\mathrm{H}-3, \mathrm{I}-129, \mathrm{C}-14$, and $\mathrm{Kr}-85$. Part I. In itial Information Base. ANL-83-57, Part I, Argonne Nat1onal Laboratory, Argonne, Il 1 inois.

U.S. DOE. 1981. Environmental Protection, Safety, and Health Protection Program for DOE Operations. DOE Order 5480.1 A, U. S. Department of Energy, Washington, D.C.

Wilhelm, J. G., J. Furrer and E. Schultes. 1976. Head-End Iodine Removal from a Reprocessing Plant with a Sol id Sorbent." In Proceedings of the 14th Air Cleaning Conference. CONF-760822, NTIS, Springfield, Virginia. 
PNL -5108

UC-86

\section{DISTRIBUTION}

No. of

Coples

OFFSIIE

B. J. Baxter

G. A. Technologies, Inc.

P. O. Box 81608

San Diego, CA 92138

J. 0. Blomeke

Oak Ridge National Laborato

P. O. Box $X$

Oak Ridge, TN 37830

R. A. Brown

Westinghouse Idaho Nuclear Co., Inc.

P. 0. Box 4000

Idaho Fal 1s, ID 83401

W. D. Burch

Oak Ridge National Laboratory

P. 0. Box $X$

Oak Ridge, TN 37830

L. Burris

Argonne National Laboratoryry

9700 So. Cass Avenue

Argonne, IL 60439

J. D. Christian

Westinghouse Idaho

Nuclear Co., Inc.

P. 0. Box 4000

Idaho Fal 1s, ID 83401

V. R. Deitz

Naval Research Laboratory

Washington, DC 20375
No. of

Copies
R. J. Jubin

Oak Ridge National Laboratory P. O. Box $X$

Oak Ridge, TN 37830

J. H. Kittel OTD

Argonne National Laboratory

9700 So. Cass Avenue

Argonne, IL 60439

T. R. Thomas

Westinghouse Idaho Nuclear Co., Inc.

P. 0. Box 4000

Idaho Falls, ID 83401

R. G. Wymer

Oak Ridge National Laboratory P. 0. Box $X$

Oak Ridge, TN 37830

10 H. E. Stelling

U.S. Department of Energy

GTN - NE-44

Washington, DC 20545

27 DOE Technical Information

Center

Distr-1 
No. of

Copies

\section{ONSITE}

4 DOE Richland Operations Office

M. W. Shupe

F. R. Standerfer

J. D. White

H. E. Ransom

3 Rockwell Hanford Operations
R. M. Orme
R. C. Roal
W. W. Schulz

Westinghouse Hanford Company

R. E. Lerch

Pacific Northwest Laboratory

W. F. Bonner

F. P. Brauer

J. B. Brown

L. L. Burger (5)

W. A. Glass

J. H. Jarrett

W. E. Kennedy, Jr.

D. E. Knowlton/R. W. Goles

L. T. Lakey

J. L. MCE Troy

$P$. J. Mellinger (5)

B. A. Napier

R. D. Scheele (5)

R. G. Schreckhise

J. K. Soldat (5)

D. L. Strenge

C. M. Unruh

Technical Library (5)

Publishing Coordination (2) 